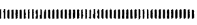

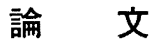

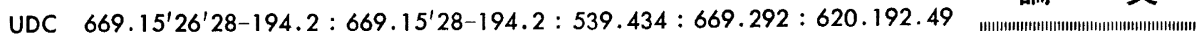

\title{
鋼のクリープぜい化におよぼす金属学的因子の影響*
}

高 松 利 男**.乙 黒 靖 男***
塩 塚 和 秀**. 橋 本 勝 邦**

\section{Effects of Metallurgical Variables on Creep Embritllement of Steels}

Toshio Takamatsu, Yasuo Otoguro,

Kazuhide Shiotsuka, and Katsukuni Hashimoto

\begin{abstract}
Synopsis:
The effects of metallurgical variables on creep embrittlement of steels for use of boiler and chemical reactor vessels were investigated.

The correlation between laboratory studies and failure cases of actual vessels was examined.

The following results were obtained.

(1) There existed the lowest creep ductility range for a steel at a certain Larson-Miller's parameter.

(2) Most severe embrittlement ocurred in coarse grain region of $\mathrm{HAZ}$ (heat affected zone) of weldment.

In order to improve the embrittlement of the $\mathrm{HAZ}$, treatments as stress relief annealing of higher temper parameter or rapid heating similar to heat cycles in fine grain region of HAZ were most effective.

(3) Detrimental effects due to impurities on the creep ductility ocurred only in synthetic HAZ specimens for $11 /{ }_{4} \mathrm{Cr}-1 /{ }_{2}$ Mo steels. The effect of $\mathrm{P}$ on the creep embrittlement was smaller than that of $\mathrm{Cu}$ and $\mathrm{Sb}$. The degree of the embrittlement corresponded to notch weakening as for the creep rupture strength.

(4) Examination of a defect found by NDI at the welded joint in a reactor vessel showed that the cracks initiated at the root of the weldment and that the segregation of impurities on the grain boundaries in $\mathrm{HAZ}$ was extremely high.
\end{abstract}

\section{1. 緒言}

一般に高温で鋼材を長時間使用すると材質が劣化する ことはよく知られているが，この問題は重油直接脱硫装 置に用いられた $21 / 4 \mathrm{Cr}-1 \mathrm{Mo}$ 鋼にみられる衝撃遷移温度 の上昇, すなわち勤性低下のような低温の問題（以下単 にぜい化と記す）とクリープ破断試験に拉いて破断延性 が著しく低下し，切欠き弱化をもたらす高温での問題 （以下クリープぜい化と記す）に大別される.

前者は 1 種の焼もどしぜい化であるといわれており， 鋼中の微量不純物の粒界偏析に起因していると考えられ ている.これに関してはすでに数多くの報告2) 7があ る.
後者は低合金鋼，ステンレス鋼，固溶窒素量の高い炭 素鋼などにみられる現象であるが，その原因については 不純物の粒界偏析，炭化物の析出形態や分散状況の変化 など諸説1)8) 12)があり，まだ十分に明らかにされていな い.

このクリープぜい化現象は $1 / 2 \mathrm{Mo}$ 鋼においては母材 でも影著に認められるか，高温化学装置用材料として広 く利用されることの多い Cr-Mo 鋼では母材でのぜい化 は小さい。

しかし実装置では溶接熱影響部に割れが発生する事例 が認められ，これとクリープぜい化との関連性が論議さ れているが, 従来溶接部のクリープぜい化の研究が少な く，その原因の解明および対策が十分ではなかつた.

* 昭和 51 年 10 月, 昭和 53 年 10 月本会陆演大会にて発表 昭和 53 年 12 月 1 日受付 (Received Dec. 1, 1978)

** 新日本製鉄 (株)製品技術研究所 (Products R \& D Laboratories, Nippon Steel Corp., 5-10-1 Fuchinobe Sagamihara 229)

*** 新日本製鉄 (株)製品技術研究所 工博 (Products R \& D Laboratories, Nippon Steel Corp.) 
Table 1. Commercial boiler tubes and plates used in the experiment $I$.

\begin{tabular}{|c|c|c|c|c|}
\hline \multicolumn{2}{|r|}{ Steel } & Shape and size & \begin{tabular}{c|} 
Heat \\
Treatment
\end{tabular} & $\begin{array}{l}\text { No. of } \\
\text { charge }\end{array}$ \\
\hline STBA 12 & \multirow{3}{*}{$M n-1 / 2 M o$} & $50.8 \phi \times 7 t$, tube & I.A. & 4 \\
\hline \multirow{2}{*}{ A204B } & & $29 t, 5 / t$, plate & $\mathrm{N}$ & 2 \\
\hline & & $24 \mathrm{t}, 30 \mathrm{t}$, plate & N.SR. & 2 \\
\hline A302B & $\mathrm{Mn}-1 / 2 \mathrm{Ni}-1 / 2 \mathrm{Mo}$ & $56 \mathrm{t}, 150 \mathrm{t}$, plate & N.T.SR. & 2 \\
\hline STBA23 & \multirow{2}{*}{$11 / 4 \mathrm{Cr}-1 / 2 \mathrm{Mo}$} & $50.8 \% \times 7 t$, tube & I.A. & 3 \\
\hline A387-11 & & plate & N.T. & 1 \\
\hline A387-12 & $1 \mathrm{Cr}-1 / 2 \mathrm{Mo}$ & plate & $\mathrm{N}$ & 1 \\
\hline STBA24 & \multirow{3}{*}{$.21 / 4 \mathrm{Cr}-1 \mathrm{Mo}$} & $48.6 \& \times 7 \mathrm{t}$, tube & I. A. & 4 \\
\hline \multirow{2}{*}{ A $387-22$} & & $28 \mathrm{t}, 100 \mathrm{t}$, plate & N.T. & 2 \\
\hline & & $270 t$ & N.T.SR. & 2 \\
\hline
\end{tabular}

本報告では ( I ) Mo 鋼, Cr-Mo 鋼母材のクリープぜい 化におよぼす成分と熱処理の影響を検討し，ついで(II) 炭素鋼, $1 / 2 \mathrm{Mo}$ 鋼, $21 / 4 \mathrm{Cr}-1 \mathrm{Mo}$ 鋼の溶接熱影響部各位 置のぜい化度を母材と比較して調査した．その結果，母 材にくらべて溶接熱影響部のぜい化が非常に影著なこと がわかつたので，（III） $11 / 4 \mathrm{Cr}-1 / 2 \mathrm{Mo}$ 鋼についてぜい化 とクリープ破断強度の切欠感受性扰よび不純物元素との 関連性を調査し，あわせてオージェ電子分光分析により 不純物元素の挙動を調べた. また実際の反応容器に発生 したき裂々不純物の粒界偏析状況を調査し, 上述の実験 室试験との対応を検討した。

\section{2. 実 験方 法}

（I）の熱処理の影響については Table 1 に示す市販 のボイラ鋼管およびボイラ鋼板を使用した. クリープ破 断試験は平行部 $6 \phi \times 30 \mathrm{~mm}$ (G.L.) の試験片を用い, $1 / 2$ Mo 鋼は $450 \sim 500^{\circ} \mathrm{C}, 1 \mathrm{Cr}-1 /{ }_{2} \mathrm{Mo}, 11 /{ }_{4} \mathrm{Cr}-1 /{ }_{2} \mathrm{Mo}$ 鋼は $500 \sim 600^{\circ} \mathrm{C}, 21 /{ }^{1} \mathrm{Cr}-1 \mathrm{Mo}$ 鋼は $500 \sim 650^{\circ} \mathrm{C}$ で最長 $10^{4}$ $\mathrm{h}$ 行つた.

次に(II)の実験においては Table 2 に示す化学組成 の市販の厚板(板厚 $30 \sim 80 \mathrm{~mm}$ ) を用いた．各鋼とも溶 接熱影揞部各位置の性質を明らかにする目的で, 溶接熱 サイクル再現装監により各種の熱履歴を与えた. 熱サイ クル条件は最高加熱温度を $1350^{\circ} \mathrm{C}$ (粗粒域) $\sim 900^{\circ} \mathrm{C}$ (細粒域) とし, 冷却条件は $800 \sim 500^{\circ} \mathrm{C}$ 間の冷却時間
Table 3. Chemical compositions of steels used in the experiment III.

\begin{tabular}{|l|c|c|c|c|c|c|c|}
\hline & $\mathrm{C}$ & $\mathrm{Si}$ & $\mathrm{Mn}$ & $\mathrm{Cr}$ & $\mathrm{Mo}$ & \multicolumn{2}{|c|}{ Others } \\
\hline E1 & 0.158 & 0.68 & 0.53 & 1.22 & 0.54 & - & - \\
\hline E2 & 0.166 & 0.68 & 0.52 & 1.23 & 0.54 & $\mathrm{Al}$ & 0.015 \\
\hline E3 & 0.155 & 0.69 & 0.56 & 1.23 & 0.53 & $\mathrm{P}$ & 0.042 \\
\hline E4 & 0.145 & 0.65 & 0.54 & 1.22 & 0.54 & $\mathrm{Cu}$ & 0.064 \\
\hline E5 & 0.149 & 0.69 & 0.55 & 1.22 & 0.54 & $\mathrm{Cu}$ & 0.182 \\
\hline E6 & 0.153 & 0.67 & 0.56 & 1.24 & 0.55 & $\mathrm{Sb}$ & 0.022 \\
\hline E7 & 0.148 & 0.67 & 0.54 & 1.23 & 0.54 & $\mathrm{Sb}$ & 0.042 \\
\hline E8 & 0.156 & 0.66 & 0.54 & 1.23 & 0.54 & $\mathrm{Ni}$ & 0.16 \\
\hline E9 & 0.154 & 0.71 & 0.58 & 1.23 & 0.54 & $\mathrm{Nb}$ & 0.02 \\
\hline E10 & 0.154 & 0.67 & 0.55 & 1.21 & 0.54 & $\mathrm{~V}$ & 0.01 \\
\hline E11 & 0.151 & 0.70 & 0.57 & 1.22 & 0.54 & $\mathrm{Ti}$ & 0.02 \\
\hline
\end{tabular}

を $20 \mathrm{~s}$ とした。熱サイクル付与後応力除去焼なまし (以下 SR と記载) 相当の熱処理を施した. 処理条件を Table 2 に併記する.

クリープ破断試験は $450,500,550^{\circ} \mathrm{C}$ の各温度で最長 $10^{4} \mathrm{~h}$ 行い, 強度ならびに破断延性を母材と比較した.

(III)の実験においては, Table 3 に示すように 11/4 $\mathrm{Cr}-1 / 2 \mathrm{Mo}$ 鋼に钽量元素を添加した鋼を $10 \mathrm{~kg}$ 高周波溶 解炉で溶製し, 鍛造後 Table 4 に示す熱処理を施し た. 溶接熱サイクルは，高周波でピーク温度まで加熱 し，800〜 $500^{\circ} \mathrm{C}$ を $20 \mathrm{~s}$ で通過与る冷却条件で付与し た.クリープ破断試験片は平滑扎よび切欠き試験片を用 い, クリープぜい化と切欠き弱化の関係を調べた。

クリープ破断試験は $550^{\circ} \mathrm{C}$ で約 $5 \times 10^{3} \mathrm{~h}$ まで行い, $10^{3} \mathrm{~h}$ での破断伸びと $10^{3}$ および $10^{4} \mathrm{~h}$ の破断応力で此 較を行つた。

\section{3. 実 験 結 果}

\section{1 低合金鍋の母材のクリープぜい化}

母材のクリープぜい化は $1 / 2 \mathrm{Mo}$ 鋼において顕著なこ とがよく知られて拈り, Fig. 1 に示すように板材は 450 $\sim 550^{\circ} \mathrm{C}$ で $1000 \mathrm{~h}$ 程度で $10 \%$ 以下に延性が低下して いる.クリープぜい化した試験片と延性のある試験片の 組織を比べると, 延性のある試験片は結晶粒の変形が大 きいのに対し，ぜい化材では粒変形がほとんどなく，引 張り方向にほぼ垂直なフェライト粒界にき裂が生じてい

Table 2. Chemical compositions and SR conditions of steels used in the experiment II.

\begin{tabular}{c|c|c|c|c|c|c|c|c}
\hline & $\mathrm{G}$ & $\mathrm{Si}$ & $\mathrm{Mn}$ & $\mathrm{P}$ & $\mathrm{S}$ & $\mathrm{Gr}$ & Mo & SR. \\
\hline $\mathrm{S} 1$ & 0.26 & 0.26 & 0.84 & 0.020 & 0.007 & - & - & $625^{\circ} \mathrm{C} \times 56 \mathrm{~min}, 6 \mathrm{~h}$ \\
\hline S 2 & 0.18 & 0.27 & 0.85 & 0.008 & 0.007 & - & 0.49 & $650^{\circ} \mathrm{C} \times 70 \mathrm{~min}, 6 \mathrm{~h}$ \\
\hline S 3 & 0.11 & 0.22 & 0.52 & 0.011 & 0.006 & 0.25 & 0.98 & $675^{\circ} \mathrm{C} \times 16 \mathrm{~h}$ \\
\hline
\end{tabular}


Table 4. Heat treatment conditions of steels used in the experiment III.

\begin{tabular}{l|c|c}
\hline & Procedure of treatment & Heat treatment conditions \\
\hline Base metal & $N, T, S R$ & $N: 920^{\circ} \mathrm{G} \times 2 \mathrm{~h} \rightarrow$ Controlled cooling \\
$T: 720^{\circ} \mathrm{G} \times 2 \mathrm{~h} \rightarrow$ Air cooling \\
$S R: 720^{\circ} \mathrm{C} \times 2 \mathrm{~h} \rightarrow$ Furnace cooling
\end{tabular}

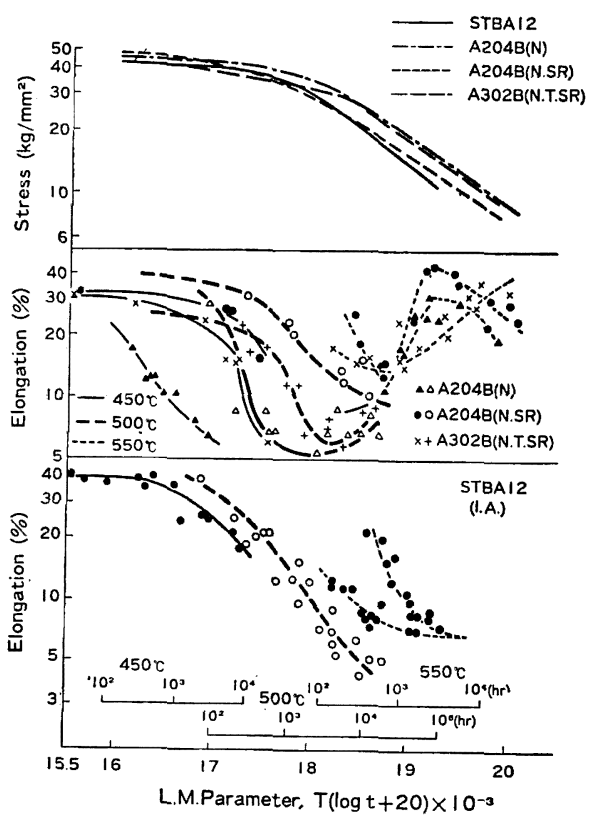

Fig. 1. Relations between creep rupture properties and Larson-Miller's parameter for $1 / 2 \mathrm{Mo}$ and $1 / 2 \mathrm{Mo}-1 / 2 \mathrm{Ni}$ steels.

ろ.

1/2Mo 鋼でも用途によつて若干組成や熱処理が異なつ ているが, Larson Miller のパラメータ（以下 T.P. と表示) で整理したクリープ破断強度のマスターカーブ ではこれらの違いはほとんど現われない。

しかし延性については，鋼板と鋼管あるいは鋼板でも 組成や熱処理によつて傾向が異なり，鋼板は $T . P .18$ 付近に延性の最低点があるのに対し，鋼管の場合は $T$. P. の高い部分での実験点がないが，19〜20 のあたりに 最低点が移るようである.これは鋼管が等温焼なましを 行つているためで, 粒内と粒界の強度差が減少すること によると考えられる.このことは PICKerIng の解説 ${ }^{13)}$ にも述べられてい特り，クリープ破断伸びがある $T . P$. で最低值をとることとも関連している.すなわちこの最 低值は，応力とそれに対応する破断時間に関係するもの である，つまり粒界き裂の生成成長と時間の経過にとも なら粒内強度の低下（当然炭化物の形状, 分散とも関連

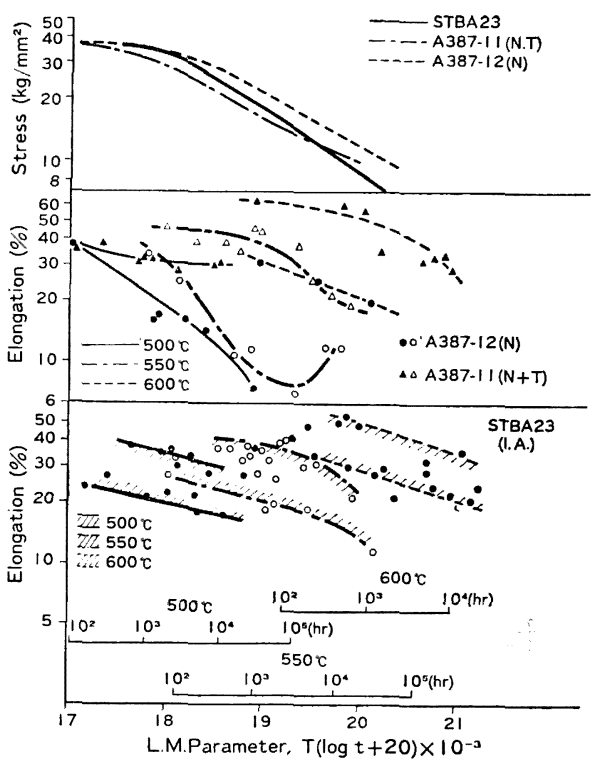

Fig. 2. Relation between creep rupture properties and Larson-Miller's parameter for $1 \mathrm{Cr}$ $1 / 2$ Mo and $11 / 4 \mathrm{Cr}-1 / 2 \mathrm{Mo}$ steels.

しているが）のどちらが優先するかによつて破壊の形式 すなわち延性がきまると考学られている，応力がきわめ て低く，破断時間が長くなると後者の寄与が大きくなり 延性が回復してくる.

また同じ 1/2Mo 鋼でも強度の高いA302 Bは，N.T. SR. を行つてもある T.P. で1桁の伸びにまで低下す る.

次に $1 \mathrm{Cr}-1 / 2 \mathrm{Mo}$ 鋼 $(\mathrm{A} 387-12), 11 / 4 \mathrm{Cr}-1 /{ }_{2} \mathrm{Mo}$ 鋼 (A 387-11,STBA23)のクリープ破断強度特性を Fig. 2 に 示すが，破断強度は，A387-12 の焼ならし材が若干高 く，破断伸びは逆に低下がかなり急激である、A387-11 と STBA23 は, $500 \sim 600^{\circ} \mathrm{C}$ の温度範囲で破断伸びが 時間とともにゆるやかに低下している.このA387-12 と の違いは若干の成分の違いによるよりはむしろ熱処理の 違いにもとつくくの考光られ，前述の $1 / 2 \mathrm{Mo}$ 鋼の場合 と同棣に焼ならしにくらべ，焼ならし焼もどしあるいは 等温烍もどしの方が強度が低いためといえる，いずれに しても焼ならしのまま以外の材料では伸びの值そのもの 


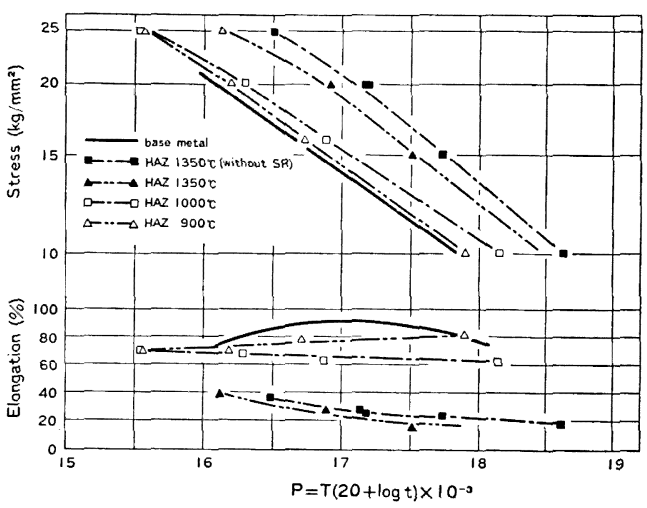

Fig. :3. Relations between creep rupture properties and Larson-Miller's parameter for base metal and synthetic HAZ of steel S1, (625 $\left.{ }^{\circ} \mathrm{G} \times 6 \mathrm{~h} \mathrm{SR}\right)$.

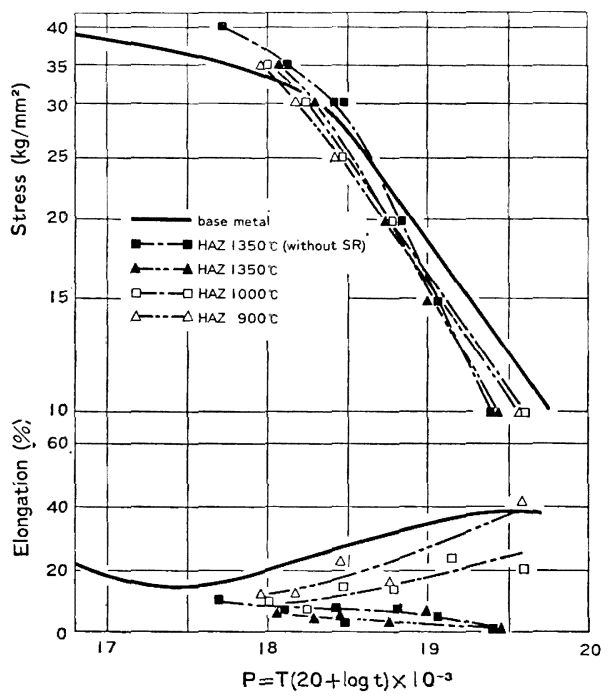

Fig. 4. Relations between creep rupture properties and Larson-Miller's parameter for base metal and synthetic HAZ of steel S2, (650 ${ }^{\circ} \mathrm{C} \times 70 \mathrm{~min} \mathrm{SR}$ ).

は十分高いので問題となることはない.

A387-22 については $500 \sim 650^{\circ} \mathrm{C}$ の温度範囲では, 高 温ほと長時間側で破断延性が低下しているが，いずれの 温度でも20\%以上は確保されて拈り，問題は少ない.

結局破断延性の低下は Mo 鋼よりは Cr-Mo 鋼の方 が軽度であり，しかも後者の中でも $\mathrm{Cr}$ 量の高い方がぜ い化が少ない。

\section{$3 \cdot 2$ 溶接熱サイクルとクリープぜい化}

前項において低合金鋼の母材におけるクリープぜい化 について述べたが，実装直での事故例は溶接熱影響部
(以下 HAZ と記載) に集中していることから， HAZ のクリープぜい化を調べる方が実用性が大きい。

この場合溶接継手では HAZ 位置の影貔が詳細に把握 できないため，溶接熱サイクル再現装置で試験片を作成 したが，均熱部が狭いため，平行部を $10 \mathrm{~mm}$ とした. 比校のため母材も同一の試験片を用いている.

炭素鋼 S1 について，再現熱影響部のクリープ破断特 性を Fig. 3 に示すが，破断強度は再現熱サイクルのピ ーク温度が高いほど高い值を示す. 破断伸びについては 逆の傾向を示し，とくにピーク温度 $1350^{\circ} \mathrm{C}$ の場合は母 材にくらべ著しく延性が低下する．これは後述する 1/2 Mo 鋼, 21/4 Cr-1Mo 鋼もまつたく同様の傾向であり, TIPLER ${ }^{14)}$ の $\mathrm{Cr}-\mathrm{Mo}-\mathrm{V}$ 鋼に関する研究でも報告されて いる. また $625^{\circ} \mathrm{C} \times 6 \mathrm{~h}$ の SR によつては, $1350^{\circ} \mathrm{C}$ $\mathrm{HAZ}$ の延性の改善はまつたく認められない，しかし伸 びの絶対值は約 $20 \%$ あり，実質的に問題になるほど低 い值ではない.クリープ破断試験前後の顕徽鏡組織を観 察した結果では破断延性の高い試料は粒の塑性変形と空 隙が，また破断延性の小さい試料は鋭い粒界き裂が観察 される.

Fig. 4 に 1/2 Mo 鋼の S2 について, 母材と HAZ の クリープ破断応力扣よび破断延性と T.P. および再現熱 サイクルのピーク温度の関係を示す. 破断強度は母材に くらべて全般的に低い傾向を示し, HAZ の弱化が顕著 なことを示している. またこの鋼板の場合は N.T.SR 処理のため母材そのものの破断延性が比較的高いが，あ るT.P.の点から延性がふたたび増大する現象がみられ ることは前項で述べたのとまつたく同じ傾向である．ピ ーク温度が $1200^{\circ} \mathrm{C}$ 以上では延性が $10 \%$ 以下と著るし く低下するが，ピーク温度が $1000^{\circ} \mathrm{C}$ 以下と比較的近い 場合は母材と傾向が類似している.

$1 / 2 \mathrm{Mo}$ 鋼の母材および HAZ のクリープ破断試験片 の割れ近傍の組織の違いは，母材が粒内変形が大きく空 隙が多数見られるのに反して破断伸びがわずかに $1 \%$ の ピーク温度 $1350^{\circ} \mathrm{C}$ 再現 $\mathrm{HAZ}$ 試験片は旧オーステナ イト粒界に鋭いき裂が入り，粒の変形をほとんど伴つて いない. したがつて HAZ のクリープぜい化には旧ォー ステナイト粒界が主たる役割を果していることがわか る. 熱サイクル後の SR の効果については，焼なましの T.P. が $18.5 \sim 18.7$ 程度 $\left(650^{\circ} \mathrm{C} \times 70 \mathrm{~min}, 650^{\circ} \mathrm{C} \times 6 \mathrm{~h}\right)$ ではクリープぜい化のもつとも激しい部分の延性改善に 何ら貢献していない.したがつて破断後の組織も注とん ど変りはなく，旧オーステナイト粒界に沿つて割れてい る.

Fig. 5 に 21/4 Cr-1Mo 鋼再現熱サイクル試験片につ 


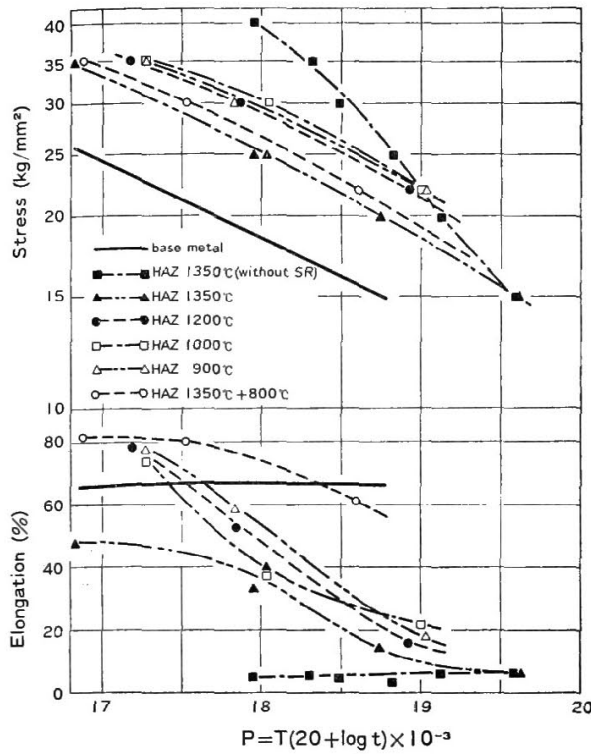

Fig. 5. Relations between creep rupture properties and Larson-Miller's parameter for base metal and synthetic HAZ of steel S3, (675 $\left.{ }^{\circ} \mathrm{G} \times 16 \mathrm{~h} \mathrm{SR}\right)$.
いてのクリープ破断強度打よび破断伸びと T.P.の関係 を示す。 ピーク温度 $1350^{\circ} \mathrm{C}$ の場合は， $\mathrm{SR}$ を施さな いと T.P. $18\left(500^{\circ} \mathrm{C}\right.$ で約 $\left.1600 \mathrm{~h}\right)$ でも破断伸びは数\% に低下してしまう。しかし $675^{\circ} \mathrm{C} \times 16 \mathrm{~h}$ の SRを行う と破断伸びが数\%まで低下する T.P.は 19.6 程度まて 大きくなり，クリープぜい化の改善に対して SR の効 果が羿められるよらになる.このことは多層盛りを想定 した場合の再熱サイクルのピーク温度が $800^{\circ} \mathrm{C}$ の時, 延 性が著しく向上することに関連があると考えられる。

したがつて $21 / 4 \mathrm{Cr}-1 \mathrm{Mo}$ 鋼ではクリープゼい化を SR によつて改善することが期待できる. $1350^{\circ} \mathrm{C}$ 加熱後の 再熱サイクルのピーク温度が 900〜 $1200^{\circ} \mathrm{C}$ のものでは プロットが重複するので省略するが，その温度に 1 回の 熱サイクルを与えた場合と同じ程度にをで延性が回復し て扣り, $800^{\circ} \mathrm{C}$ の場合ほどではないが，1回目の $1350^{\circ} \mathrm{C}$ の熱サイクルの悪影響を打ち消す効果が認められる.こ れと同じ傾向は $1 / \mathbf{2}$ Mo 鋼においても同様に 観察されて いる.すなわち多層溶接の場合には前の溶接ビードによ る HAZ は次回以降の溶接ピードによりピーク温度の低 い熱サイクルを受けるため，クリープぜい化傾向が軽減 されて，実質的に問題となるのは最終層による $\mathrm{HAZ} と$ 考えられる。

Photo. 1 に $2 \frac{1}{4} \mathrm{Cr}-1 \mathrm{Mo}$ 鋼のクリープ破断試験片の

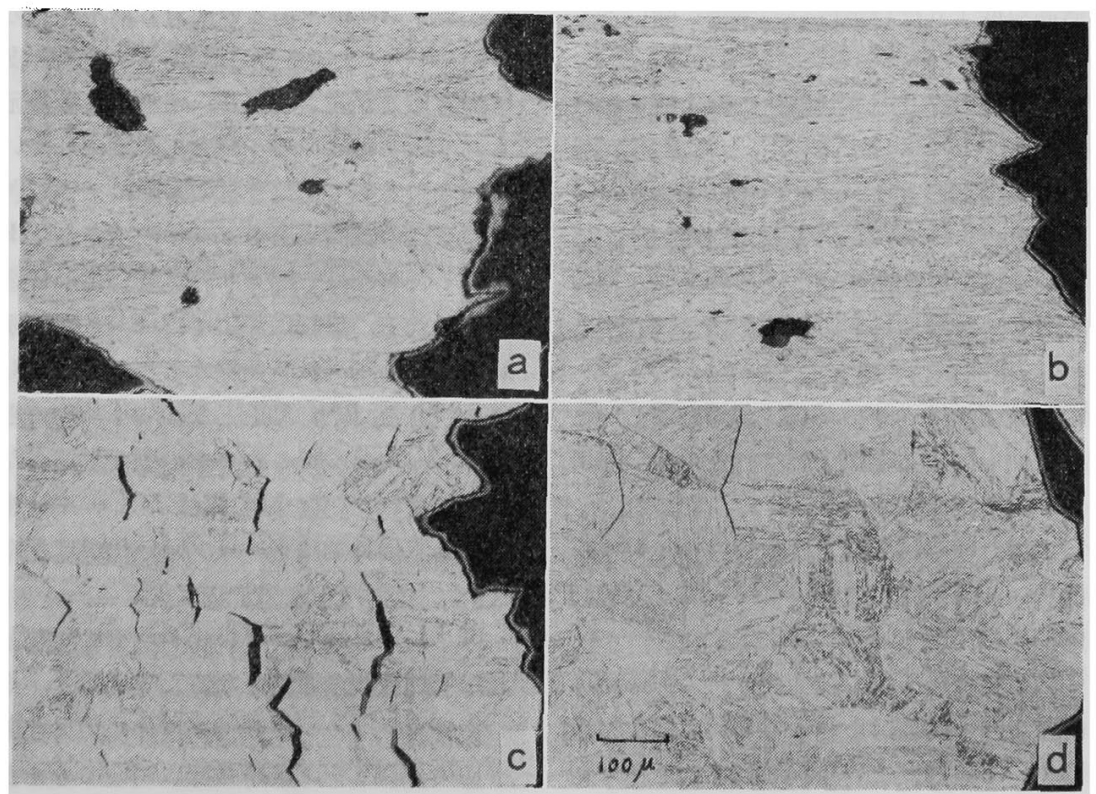

a) Synthetic $\mathrm{HAZ}$ (peak temp. $1350^{\circ} \mathrm{C}+800^{\circ} \mathrm{C}$ ), $\sigma 22 \mathrm{~kg} / \mathrm{mm}^{2}, \operatorname{tr} 405 \mathrm{~h}$, el. $61 \%$

b) Synthetic HAZ (peak temp. $900^{\circ} \mathrm{C}$ ),

c) Synthetic HAZ (peak temp. $1200^{\circ} \mathrm{G}$ ),

o $22 \mathrm{~kg} / \mathrm{mm}^{2}$, tr $1364 \mathrm{~h}$, el. $18 \%$

d) Synthetic HAZ (peak temp. $1350^{\circ} \mathrm{C}$ ),

$\sigma 22 \mathrm{~kg} / \mathrm{mm}^{2}$, tr $1007 \mathrm{~h}$, el. $16 \%$

$\sigma 15 \mathrm{~kg} / \mathrm{mm}^{2}, \operatorname{tr} 6480 \mathrm{~h}$, el. $7 \%$

Photo. 1. Fracture profiles of creep ruptured specimens of steel $\mathrm{S} 3,\left(550^{\circ} \mathrm{G}\right)$. 
光顕組織を示す。. (d) のピーク温度 $1350^{\circ} \mathrm{C}$ の再現 $\mathrm{HAZ}$ 組織は粗大な旧オーステナイト結晶粒界に鋭いき裂が認 められるが，(c)のピーク温度 $1200^{\circ} \mathrm{C}$ の場合は粒度も 小さくなり，き裂長さも短かく幅をもつた小き裂が多数 にみられるよらになり，粒界に沿つてき裂が進展しにく くなる様相を示す。

さらに低い $900^{\circ} \mathrm{C}$ のピーク温度の場合には, (b)に示 されるよらに結晶粒がきわめて細かくなり，塑性変形が 生じて空陌が認められるよらになる。（a）は熱サイクル を 2 回受けた場合 $\left(1350^{\circ} \mathrm{C}+800^{\circ} \mathrm{C}\right)$ で, 組織的には (b) と同様に結晶も細かく，空隙の出方もまつたく同様であ るにもかかわらず，破断延性は $61 \%$ と 3 倍も高い。 こ のことは $900^{\circ} \mathrm{C}$ と $800^{\circ} \mathrm{C}$ の両温度がそれぞれ $\mathrm{Ac}_{3}$ 变 態点の上下に相当するため, $900^{\circ} \mathrm{C}$ 処理材は焼入状態， $800^{\circ} \mathrm{C}$ 処理材は 2 相域での焼もどし状態にあたることか ら由来するものと考えられる。つまり前項にお忚る母材 の場合と違つて HAZ のクリープ破断は主として旧オー ステナイト粒界で生ずることから，この粒界が連続して 残された状態は好ましくないといえる。

再現熱サイクルを受けたクリープ破断試験片の破面 は, ピーク温度 $1350^{\circ} \mathrm{C}$ の場合はいずれも粒界破面を呈 しているが，その結晶は炭素鋼がもつとも大きい，乙か しぜい化傾向は $1 / 2 \mathrm{Mo}$ 鋼，21/4 $\mathrm{Cr}-1 \mathrm{Mo}$ 鋼の方が大き いことから，結晶粒度よりは合金成分の影響が強いこと を示している.

\section{$3.311 / 4 \mathrm{Cr}-1 / 2 \mathrm{Mo}$ 銅のクリープぜい化におよぼす得 元素の影響}

以上の結果から合金鋼のクリープぜい化は HAZ 粗粒 部においてのみ顕著なことが明らかとなつたので，その 1 例として $11 / 4 \mathrm{Cr}-1 / 2 \mathrm{Mo}$ 鋼を用い, 不純物元素, 細粒 化元素のクリープぜい化特性におよぼす影響を検討し た.

まず，HAZ 粗粒部ではクリープぜい化がきびしいこ とから，切欠感受性も高いことが予想されたので，平滑 材と切欠材についてクリープ破断試験を行つた。

また，HAZ と母材での切欠感受性の相違を比較する ために，母材についても平滑材と切久材のクリープ破断 試験む行つた．結果の 1 例を Fig. 6 に示す.

一般に延性のある材料に招いては切欠き材の力が塑性 拘束のため平滑材よりも強い，いわ功る切欠き強化の現 象が認められるが，ある程度ぜい化が進行すると逆に切 欠き材の方が強度が低下する切欠き弱化の状態に移行す る. この強化状態から弱化状態への遥移点の時間を知る ことによつてもクリープぜい化の傾向を知ることが可 能と考えられる.すなわち Fig. 6 では 11/4 $\mathrm{Cr}-1 / 2 \mathrm{Mo}$

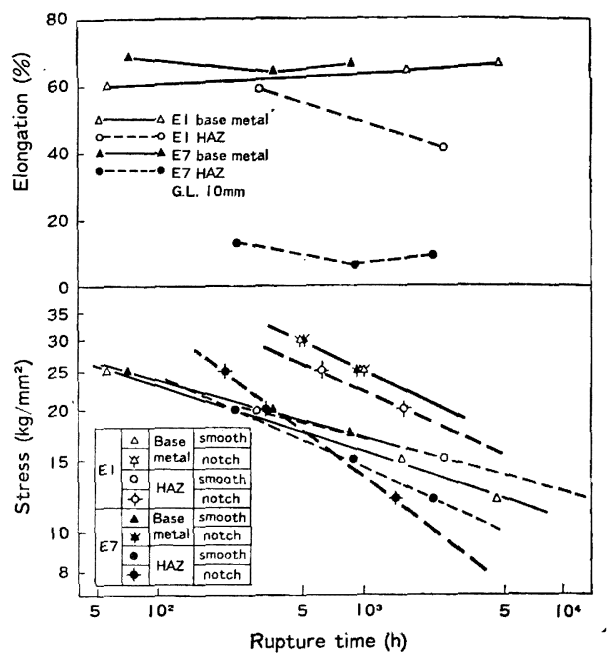

Fig. 6. Greep rupture properties of smoothed and notched specimens for steels E1 and E7, $\left(550^{\circ} \mathrm{G}\right)$.

鋼ペース材の $\mathrm{E} 1$ 鋼とそれに $0.04 \%$ の $\mathrm{Sb}$ を添加した E7 鋼について,母材と HAZ の平滑および切欠き試験片 による $550^{\circ} \mathrm{C}$ クリープ破断曲線を, 平滑試片での破断延 性と対応させて示した。

HAZ 平滑材と切欠材のクリープ破断曲線の交点は E7 で約 $700 \mathrm{~h}$ であるのに対し，不純物の少ないE1 鋼 は約 $10^{4} \mathrm{~h}$ まで延長される。この場合支配的な特性は HAZ 切欠き強さであり, 平滑材は微量元素を添加して もクリープ破断曲線がほとんど変化しないため, 交点の 時間は主として切欠き材の勾配によつてきまつてくる. この交点の時間は上のグラフに示された HAZ の伸びと 関係して捛り，一応クリープぜい化の目途となりらると 考兄られる.母材については E1,E7 両鋼とも切欠き試 験片のクリープ破断曲線はまつたく一致して括り，交点 はいずれも $10^{5} \mathrm{~h}$ 以上となつて不純物の影響は認められ ない，したがつてこれまでの項でも述べたように，T． $\mathrm{SR}$ を受けた Cr-Mo 鋼はかなり不純物の高い鋼であ つても，母材ではクリープぜい化がほとんど問題になら ない.

ところでクリープぜい化が現然に問題となるのは，そ れが早期破壊の原因となるためであり，そこで微星元素 の影響をクリープ破断伸び以外に切欠さ弱化への透移点 や切欠きクリープ破断強度についてもまとめてみた. 結 果の一部を Fig. 7 に示す. Fig. 7 は HAZ 切欠きと 平滑試験片の $550^{\circ} \mathrm{C}, 10^{3} \mathrm{~h}$ 扎よび $10^{4} \mathrm{~h}$ のクリープ破断 強度を示したものである. $10^{3} \mathrm{~h}$ では Sb $0.04 \%$ を含む E7 鋼のみが切久弱化を示している. 10`h でくらべる 


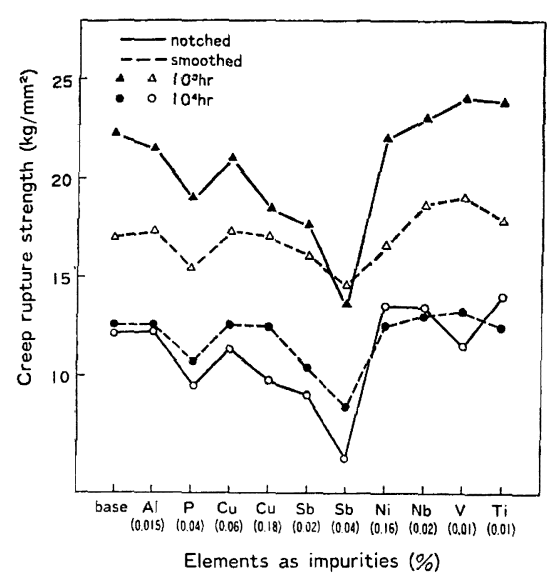

Fig. 7. Effects of impurity elements on creep rupture strength of smoothed and notched synthetic $\mathrm{HAZ}\left(1350^{\circ} \mathrm{C}\right)$ specimens of $11 / 4 \mathrm{Cr}-1 / 2$ Mo steel, $\left(550^{\circ} \mathrm{C}\right)$.

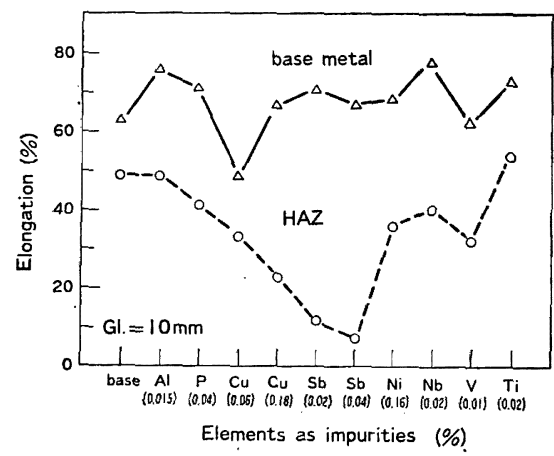

Fig. 8. Relations between creep rupture ductility and impurity elements, $\left(550^{\circ} \mathrm{C}, 10^{3} \mathrm{~h}\right)$.

と, 全般的に切欠弱化に移行している。この間の遷移時 間を表示した方がその傾向が明りよらになるので，各元

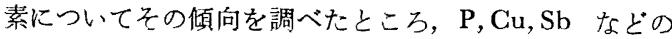
不純物を含む鋼は切久弱化一の移行が短時間で特こるこ とがわかつた。

一方溶接部での破壊挙動を知るには HAZ 切欠試験片 のクリープ強度を用いる方が現実的ともいえる。これと 微量不純物之の関係は，破断時间 $10^{3} \mathrm{~h}, 10^{4} \mathrm{~h}$ に対応与 るいずれの応力でもほとんど同じ傾向を示して拉り，之 くに $\mathrm{P}, \mathrm{Cu}, \mathrm{Sb}$ 等の效果は Fig. 8 にみられる破断延性: の関係と傾向がまつたく一致している。この中でも $\mathrm{Sb}$ の影響がるつと大きく，ぜい性に招よぼす影響について は, GoocH ${ }^{15)}$ らが $\mathrm{Cr}-\mathrm{Mo}-\mathrm{V}$ 鋼におけるき裂伝播速度 の研究で不純物の効果に対する係数を次式で提案してい $\mathrm{P}+2.4 \mathrm{As}+2.6 \mathrm{Sn}+8.2 \mathrm{Sb}(\mathrm{wt} \%)$
るが，本研究でも同程度の 定量的効果と考えられる.

$\mathrm{Al} ， \mathrm{Ti}$ のような細粒化元素は延性面で有利に働いてい る. $\mathrm{Al}$ の効果は研究者によつては有害との報告 ${ }^{16 \sim 18)}$ も あるが，組織の変化を伴う $\mathrm{Ni}, \mathrm{Nb}, \mathrm{V}$ などについてと り上げる特性によつて若干傾向が変化している．いずれ にせよ $\mathrm{P}, \mathrm{Cu}, \mathrm{Sb}$ のよらな不純物元素の影響にくらべれ ば，その影響はわずかである。

結局 HAZ 試験片については, 破断延性, 切欠弱化一 のクリープ破断時間遷移点, 切欠クリープ破断強度の間 に全体的な相関性があり，またこれらには不純物の影響 が顕著であることがわかつた，HAZ のクリープばい化 は母材の場合と異なり，旧オーステナイト粒界の性質に 低存し，炭化物の形状，分布などの影響が少ない。した がつて旧オーステナイト粒界への偏析が顕著な不純物の 影響が強く現れると考えられる，一方母材ではいずれの 整理方法でもこの程度の量では微量元素の影響はほとん ど見受けられなかつた。ただし Sb 0.04\% を添加した E7 鋼のみが切久強化から弱化一の遷移点が 短時間側に 移り，悪影響が認められた。

次に延性の異なる代表的 2 鋼種 (E7，E11) 飞拈忊る $\mathrm{HAZ}$ 平滑試験片のクリープ破断試験後のき裂の状況を Photo. 2 亿示す. 細粒化元素としてTi $0.02 \%$ を含有し ているE11 鋼は, Sb 0.04\%を含有している E7 鋼にくら べてオーステナイト粒度も小さい上，粒界き裂が鋭くな く，き裂の伝播に対する抵抗が大きいと予想される。つ まり延性の低い鋼はいつたんき裂が発生すると容易に伝 播して破壊に達するのに 対し，延性のある鋼ではき裂 の伝播が扣こりにくいため，数多くのき裂が同時に存在 する状態になると考えられる，そこで実装置との対応を 知るため，事故材の調查結果を Photo. 3(a)〜 (f) に 示す、鋼種は実験材と同じ Table 5 に示した組成の $11 / 4 \mathrm{Cr}-1 / 2 \mathrm{Mo}$ 鋼で,隅肉溶接部に括ける割れの例であ る.（a）は隅肉溶接部のマクロ写真であり，ボンド部近 傍に溶接止端部から発したと見られるかなり大きなき裂 が認められ，またそれから発達したと考兑られる微細な 割れが HAZ と母材の境界付近に観察される。それを拡 大したものが(b)でフェライト粒界に沿つた割れであ る. 初期割れの内面は厚いスヶールに覆われているので 割れが発生してからかなりの時間が経過していると考兄 られる。また（a）(b)のき裂の周辺にはとれぞれ（c)， (d) K見られるようなミクロクラックが敞在して㧍り， これはさらに時間が経過すれば(a)，(b)のようなクラ ックに発達していくものと思われる。またそのミクロク ラックの周辺には，(e)，(f)に見られるように，もと になつた粒界のボイドが観察される。 


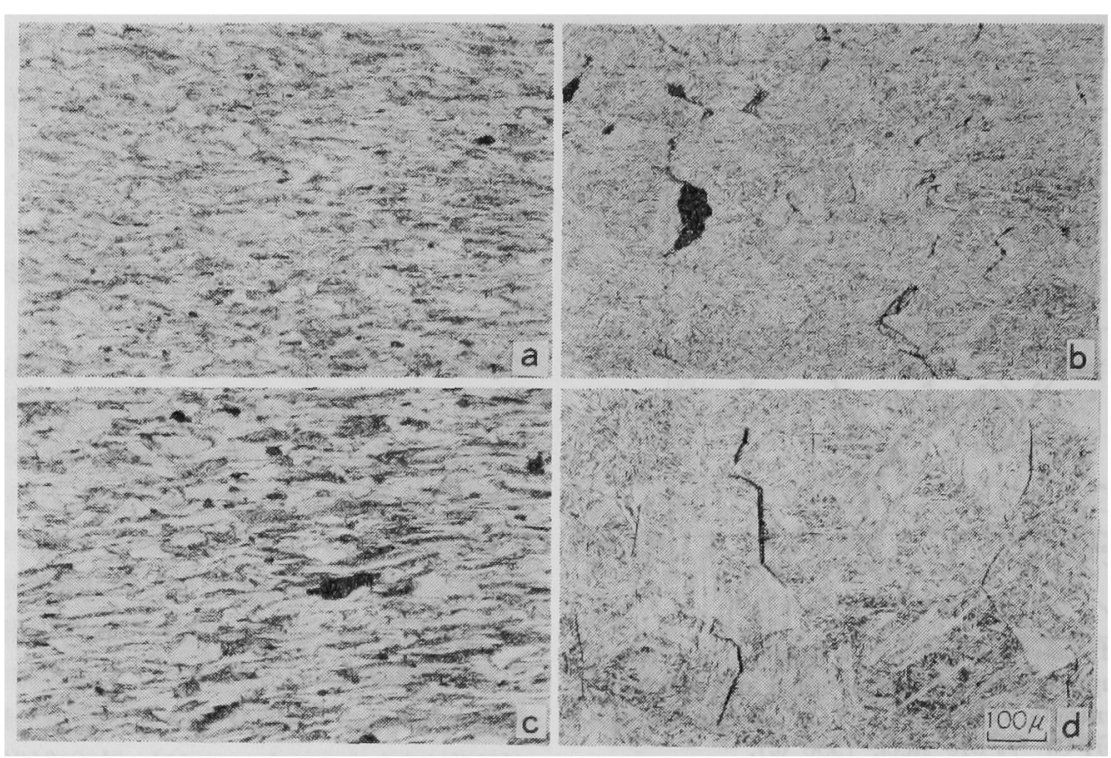
a) E11 base metal,
$\sigma 12 \mathrm{~kg} / \mathrm{mm}^{2}, \operatorname{tr} 2755 \mathrm{~h}$, el. $77.5 \%$
b) E11 synthetic HAZ, $\sigma 15 \mathrm{~kg} / \mathrm{mm}^{2}$, tr $3018 \mathrm{~h}$, el. $40.5 \%$
c) E7 base metal, $\sigma 17.5 \mathrm{~kg} / \mathrm{mm}^{2}$, tr $853 \mathrm{~h}$, el. $66.5 \%$
d) E7 synthetic HAZ, $\sigma 12 \mathrm{~kg} / \mathrm{mm}^{2}$, tr $2143 \mathrm{~h}$, el. $9.0 \%$

Photo. 2. Microstruetures of creep ruptured specimens of steele E7 and E11.

この場合の割れが HAZ 粗粒部で, しかも形状的に切 欠のある溶接止端部に発生していることから，HAZ 切 欠試験片のクリープ破断試験と同様な状況が再現された と考光られ，実験室試験の結果と良い対応を示してい る。しかし実装置では扰そらく実験のように一定の応力 ではなく, 温度変動, 温度勾配にもとづく熱応力が付加 されていると考兄られる。一般に熱疲労が加わつた場合 の方が破壊は速くおこり，設計時に想定した寿命より短 期間で割れたりする一つの要因となつている19)。この溶 接部での割れは旧オーステナイト粒界割れであるといら 点で SR 割れも予想されたが, 装置完成後磁粉探傷で 全溶接線の無欠陥を確認している。

ところで前述のように，クリープぜい化に拈いては， 焼もどしぜい化と同様に旧オーステナイト粒界での不純 物元素の偏析が大きな影響を与兄ているといわ机てい る1).

そこで $\mathrm{Sb}$ を $0.04 \%$ 含有している $\mathrm{E} 7$ 鋼で，再現熱 サイクル後 $550^{\circ} \mathrm{C}, 12 \mathrm{~kg} / \mathrm{mm}^{2}$ の応力下 $1400 \mathrm{~h}$ で破断 した陚験片と, 実装置から切り出した $11 / 4 \mathrm{Cr}-1 / 2 \mathrm{Mo}$ 鋼 の母材と HAZ について,オージェ電子分光で各種元素 を分析した結果を Fig. 9～10, Table 6 に示す. Fig. 9 は E7 鋼の粒界, または䢃開面から内部へ向つての $P$, $\mathrm{Sb}$ の偏析状態を $\mathrm{Ar}$ スパッタリングによつて測定した 結果であるが，䢃開面では不純物元素の偏析は認められ
ない，粒界にはかなりの濃度のPが検出され，界面から 約 $12.5 \AA$ 相当の個所では相対比が $1 / 2 \sim 1 / 3$ と急激に減 少し，さらに内部に入るにしたがい濃度は低減してい る.これに対して Sb は高電子ェネルギー領域にあっ て, 精度が落ちるためもあり, あまり顕著に濃度差は認 められないが，粒内の $2 \sim 3$ 倍程度の偏析はあると考克 られる。しかし前出のクリープぜい化のデータと比較し て，粒界の偏析度の非常に高い $\mathrm{P}$ は著者らの実験20)では 焼もどしぜい化にはきわめて有害であつたが，クリープ ぜい化にはそれ汪ど大きな影響は拈よぼしていないこと がわかる。これに対して Sb 泩きわめて大きな影響が ある.クリープぜい化と不純物の粒界偏析之の関係は BRUSCATO1) む指摘しているところであるが，偏析の顕著 な元素が必らずしも悪影響が強いとはいえない。

Fig. 10 は前出の実装置よりの切出しサンプルでの母 材と HAZ 粒界破断面の木ージェ電子分光分析す結果で ある、いずれも $\mathrm{P}, \mathrm{Mo}, \mathrm{C}, \mathrm{Cu}$ が検出されているが，先り

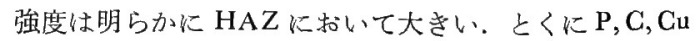
の粒界での偏析は Table 6 に示すように母材にくらべ て4〜5倍の開きがある. Sb, As, Sn などについては微 量のため HAZ，母材の差は識別できない，しかし Fig. 10 に拈いて偏析の傾向が認められているので，HAZ のクリープぜい化に有害に作用していると考兄られる. $\mathrm{Cu}$ は低融点金属でもあり，Fig. 7.8 の結果を参照して 


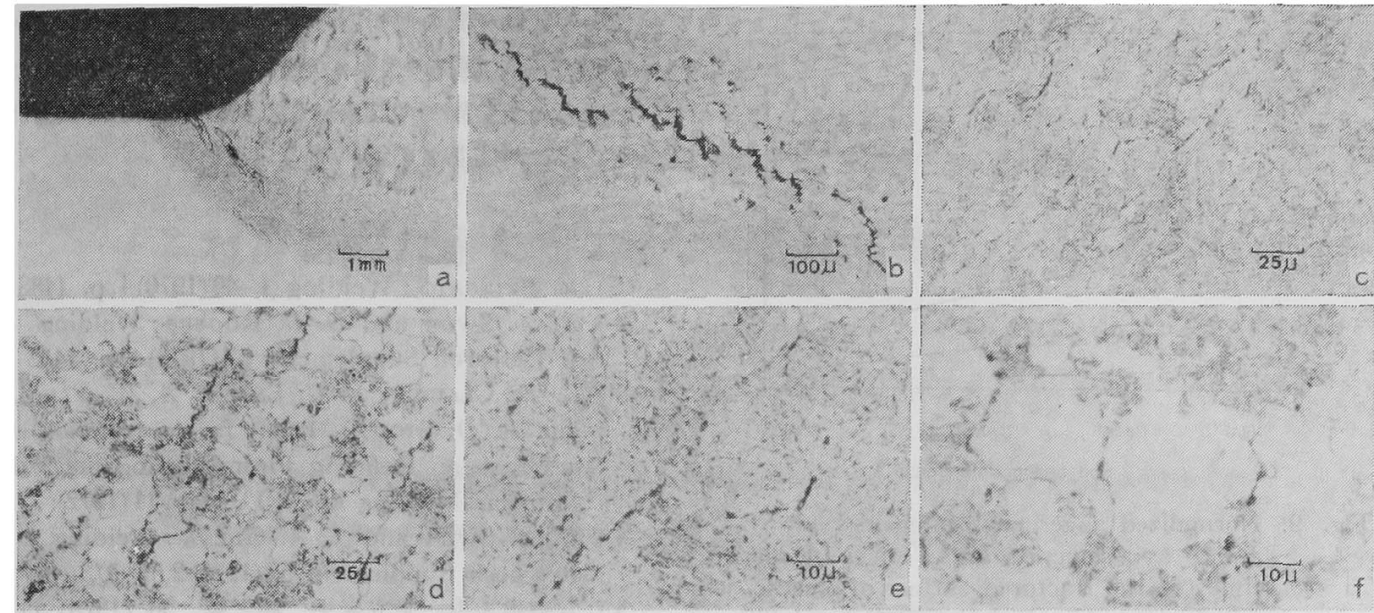

a ) Macrostructure of weldment

b) Grack propagation into HAZ/base metal boundary

c) Microcracks around main crack in HAZ

d) " " in HAZ/base metal boundary

e) Void formed around microcracks in HAZ
f)
"
in $\mathrm{HAZ} /$ base metal boundary

Photo. 3. Macrostructure and microstructures of weldment in the reactor vessel made of $11 /{ }_{4} \mathrm{Gr}-1 /{ }_{2} \mathrm{Mo}$ steel which had been used for 8 years at about $500^{\circ} \mathrm{C}$.

Table 5. Chemical compositions of steel used for Auger electron emission analysis, (wt \%).

\begin{tabular}{c|c|c|c|c|c|c|c|c|c|c}
\hline $\mathrm{C}$ & $\mathrm{Si}$ & $\mathrm{Mn}$ & $\mathrm{P}$ & $\mathrm{S}$ & $\mathrm{Cu}$ & $\mathrm{Gr}$ & $\mathrm{Mo}$ & $\mathrm{As}$ & $\mathrm{Sn}$ & $\mathrm{Sb}$ \\
\hline 0.14 & 0.72 & 0.53 & 0.015 & 0.010 & 0.18 & 1.24 & 0.52 & 0.021 & 0.018 & 0.004 \\
\hline
\end{tabular}

も有害であることは明白であり，Cも Table 6 の分析 值から粒界炭化物の存在を示唆する点で HAZのクリー プぜい化には不利な作用のあることが推測される。

\section{4. 結言}

炭素鋼，低合金鋼のクリープぜい化について，母材， 溶接部を含めて調査した。このうち問題の大きい溶接丢 影響部に関しては，再現熱サイクルを用いてて加熱ピーク 温度，再熱サイクルの影響を明らかにした。 また化学装 置に使用されることの多い Cr-Mo 鋼については，11/4 $\mathrm{Cr}-1 / 2 \mathrm{Mo}$ 鋼を選んで HAZ のクリープせ゚い化と微量元 素の関係をオージェ電子分光を用いて調へ，実装置事故 材との関連性も併せて調査した，得られた結果の要約は 以下のと捛である.

1) $1 / 2 \mathrm{Mo}$ 鋼から Cr-Mo 鋼までクリープ破断時間と ともにクリープ破断延性は低下与るが，一般的な傾向と してもつともぜい化の激しいクリープ温度が存在し, ま た ${ }^{1} / 2 \mathrm{Mo}$ 鋼のようにぜい化の顕著な鋼は低応力，長時 間破断の場合に延性が回復する.
2) 再現 HAZ 試験片のクリープ破断延性は加熱ピー ク温度が高いほど低く，とくにボンド近傍に相当する粗 粒部では著しい，母材でのクリープぜい化が生じない炭 素鋼に拈いてもかなりのぜい化が生じる・1/2Mo 鋼や $\mathrm{Cr}$-Mo 鋼では, HAZ 粗粒相当部でのぜい化は激しいが $\mathrm{SR}$ 条件あるいは $800^{\circ} \mathrm{C}$ 近辺への再熱サイクルによつて かなり改善される。

3) $11 / 4 \mathrm{Cr}-1 / 2 \mathrm{Mo}$ 鋼のクリープゼい化に打よぽす微 量元素の影響については, 舟材ではまつたく認められ お゙，HAZ のみに拈いて Sb, Cu，Pのような不純物の有 害性が認められた。Pはオージェ電子分光分析では粒界 偏析が明りようであるが, Sb にくらべてクリープぜい化 に対する作用が著しく弱い。

4) HAZ のクリープせ゚い化は，破断延性の低下，切 欠きクリープ強度の低下, 切欠強化から弱化一の早期移 行として現われるが，いずれる不純物元素の影響に関し てよい刘応が見られた。

5) 尖装置事故材の割れ钼察の結果，き裂は溶接止端 部から HAZ 粗粒部に沿つて進行していた. HAZ と目: 


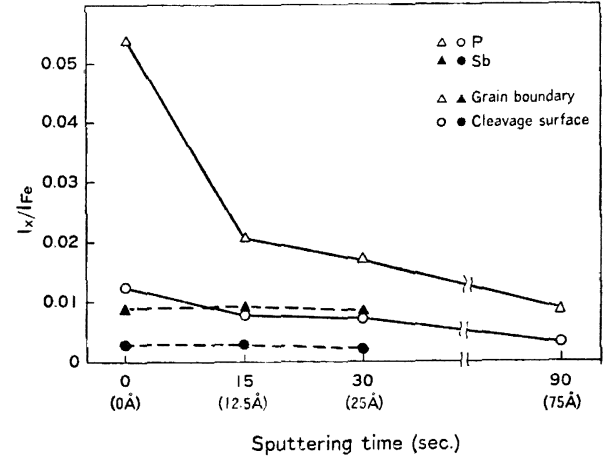

Fig. 9. Normalized auger peak intensities of $\mathrm{Sb}$ and $\mathrm{P}$ as a function of $\mathrm{Ar}$ ion sputtering time for the fractured surface of steel E7 which was embritlled at $550^{\circ} \mathrm{C}$ for 1437 $\mathrm{h}$ under the stress of $12 \mathrm{~kg} / \mathrm{mm}^{2}$.

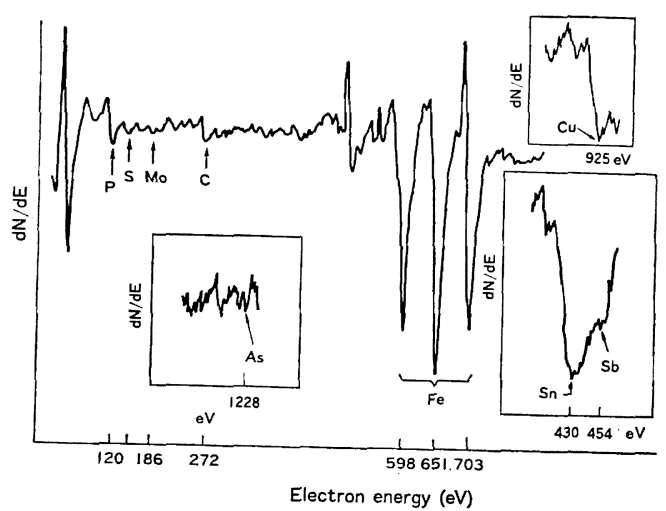

Fig. 10. Auger spectrum of fracture surface of specimen cut from HAZ region in the weldment of the reactor vessel.

Table 6. Results of Auger electron emission analysis, $\left(I_{X} / I_{\mathrm{Fe}}\right)$.

\begin{tabular}{|l|c|c|c|c|}
\hline \multirow{2}{*}{} & \multicolumn{2}{|c|}{ Base metal } & \multicolumn{2}{c|}{$\mathrm{HAZ}$} \\
\cline { 2 - 5 } & grain boundaries & cleavage surface & grain boundaries & cleavage surface \\
\hline Carbon & 0.034 & 0.042 & 0.135 & 0.080 \\
\hline Phosphorous & 0.032 & 0.013 & 0.164 & - \\
\hline Copper & 0.005 & 0.007 & 0.033 & - \\
\hline Molybdenum & 0.027 & - & 0.043 & - \\
\hline Antimony & 0.003 & 0.002 & 0.003 & 0.005 \\
\hline Arsenic & 0.002 & 0.008 & 0.005 & 0.007 \\
\hline Tin & 0.008 & - & 0.008 & - \\
\hline
\end{tabular}

材での不純物元素の偏析度の相違は $\mathrm{P}, \mathrm{C}, \mathrm{Cu}$ などに 1、て認められ，鋼材の生れが重要であることが窥われた。

これらの実装置での調查結果は実験室試験で得られた 結果とよく対応していた.

\section{交献}

1) R. Bruscato : Welding J. $49(1970) 4$, p. $148 \mathrm{~S}$

2) $R$. A. SWIFT and $H$. C. Rogers : Welding J. Research Supplement, 52(1973) 4, p. $145 \mathrm{~S}$

3 ) C. D. Clauser, L. G. Emmer, $A . W$. Pense, and $R$. D. Stout : "Paper for presentation at a session on Refining Piping during the 37th Midyear Meeting of API", May, 11 (1972)

4) R. A. Swift and J.A. GulyA : Welding J. Research Supplement, 52 (1973) 2, p. 57S

5）宮野樺太男，足立孝夫：鉄と鋼，56（1970）11, p. 153

6) K. Miyano : Paper for presentation of the API Task Group Meeting in Chicago, Feb. 20/21 (1974)

7 ）金沢正午, 中村治方, 乙黑靖男, 鈴木健夫, 橋本 勝邦，三井田 浾：鉄と鋼，59 (1973)11，p.259

8 ) $L . M . T$. Hopkin and $E . A$. Jenkinson: JISI, 200 (1962) 5, p. 356

9 ) $F$. Benes and P. Skvor: Proc. 4th Int. Symposium Heat Resisting Metallic Meterials, Vratna Polina, 1971, p. 50

10) H. R. Tipler and B. F. Hopkins : Metal Science, 10 (1976) 2, p. 47

11) C. Roper : Lukens Steel Company, RDR 68-12, June (1968)

12) C. Roper : Lukens Steel Company, RDR 69-2, Jan. (1969)

13) F. B. Pickering : Iron Steel, 41 (1968) 4, p. 148

14) $H$. R. Tipler, L. H. Taylor, G. B. Thomas, $J$. Williamson, $G$. D. Branch, and B. E. Hopkins : Metals Technology, 2(1975) 5 p. 206

15) D. J. Gooch, $J . R$. Haigh, and $B . L$. King : Metal Science, 11 (1977) 11, p. 545

16) J. L. Ratliff and R. M. Brown : Trans. ASM, 60(1967) 2, p. 176

17) $R$. Viswanathan and $A . D$. Wilson : Paper presented at the 6th Annual Spring Meeting of AIME, May, 1974 Pittsburgh Pa.

18) W. E. TRumpler : ASME Paper 67 WA MET-12, 1967

19）宮川松男：日本機械学会誌，76（1973）658, p. 92

20）金沢正午，門智，乙黒靖男，塩塚和秀，橋本 腾邦：鉄と銿，62（1976） 4, p. 284 